\title{
Pelatihan Pembelajaran Seni Musik sebagai Sarana Literasi Budaya untuk Guru Sekolah Dasar
}

\section{Music Arts Learning Training as a Means of Culture Literation for Elementary School Teachers}

Desyandri"
Zuryanty
Mansurdin
Universitas Negeri Padang, Padang,
West Sumatera, Indonesia
"email: desyandri@fip.unp.ac.id
Kata Kunci
Seni Musik
Literasi Budaya
Keywords:
Music Art
Cultural Literacy
Received: September 2019
Accepted: November 2019
Published: March 2020

\begin{abstract}
Abstrak
Latar belakang pengabdian ini adalah lemahnya pengetahuan dan keterampilan guru dalam menjadikan seni musik sebagai literasi budaya untuk guru sekolah dasar. Tujuan pengabdian ini adalah untuk meningkatkan pengetahuan dan keterampilan guru sekoalh dasar dalam pembelajaran seni musik sebagai sarana literasi budaya untuk guru sekolah dasar. Metode pengabdian ini menggunakan metode seminar dan pelatihan langsung. Hasil pengabdian menunjukan adanya peningkatan pengetahuan dan keterampilan guru dalam menjadikan pembelajaran seni musik sebagai literasi budaya untuk guru sekolah dasar. Implikasi pengabdiian ini dapat dijadikan acuan oleh guru dan praktisi pendidikan untuk meningkatkan kualitas pembelajaran seni dan kaitanya dengan literasi budaya.
\end{abstract}

\begin{abstract}
The background of this service is the lack of knowledge and skills of teachers in making music as a cultural literacy for elementary school teachers. The purpose of this service is to improve the experience and skills of primary school teachers in learning the art of music as a means of cultural literacy for elementary school teachers. This service method uses the seminar method and hands-on training. The results of the dedication showed an increase in the knowledge and skills of teachers in making music art learning a cultural literacy for elementary school teachers. The implications of this service can be used as a reference by teachers and education practitioners to improve the quality of art learning and its relation to cultural literacy.
\end{abstract} Universitas Muhammadiyah Palangkaraya. This is Open Access article under the CC-BY-SA License (http://creativecommons.org/licenses/by-sa/4.0/). DOI: https://doi.org/10.33084/pengabdianmu.v5i2.1022

\section{PENDAHULUAN}

Perubahan kurikulum 2013 disekolah dasar menetapkan pembelajaran disekolah menggunakan pembelajaran tematik terpadu. Pembelajaran tematik terpadu merupakan suatu pembelajaran yang menggabungkan beberapa pembelajaran kedalam satu tema (Scharkow, 2013). Pembelajaran tematik terpadu menuntuk kreativitasan guru untuk dapat membawakan pembelajaran secara terpadu sehingga siswa tidak merasakan adanya dominasi pembelajaran tertentu (Siew et al., 2015). Pada pembelajaran tematik terpadu mata pelajaran dibelajarkan secara bersamaan namun disesuaikan dengan tema yang telah ditetapkan (Susanto, 2013). Pada pembelajaran tematik terpadu di sekolah dasar mengalami perubahan bahwa pembelajaran matematika dan PJOK tidak dilaksanakan secara tematik dengan alasan adanya perbedaan karakteristik antara matematika dan PJOK dengan mata pembelajaran lainya. Sehingga pembelajaran yang dilaksanakan secara tematik adalah Bahasa Indonesia, PKn, IPA, IPS dan SBDP.

Untuk mengetahui proses pembelajaran kurikulum 2013, pengabdi melakukan wawancara untuk menemukan permasalahan yang terjadi di sekolah 
dasar. Pengabdi melakukan wawancara kepada kepala sekolah salah satu SD di Padang Panjang yang merupakan mahasiswa pasca sarjana di UNP. Hasil wawancara dengan Kepala Sekolah menyatakan bahwa pada umumnya semua SD yang berada di Kota Padang Panjang telah melaksanakan kurikulum 2013. Namun pelaksanaan pembelajaran tematik belum dikatakan optimal dikarenakan pada beberapa mata pelajaran yang masih dilaksanakan secara terpisah. Mata pelajaran itu adalah mata pelajaran SBDP. Mata pelajaran SBDP di ajarkan guru masih secara terpisah, dan biasanya itu dilaksanakan pada setiap hari sabtu. Ketika pengabdi menanyakan mengapa hal tersebut terjadi, kepala sekolah menyatakan bahwa guru-guru masih beransumsi pelajaran SBDP tidak bisa digabungkan dengan pelajaran lainya sehingga perlu jam kusus dalam membelajarinya. Selain itu pembelajaran yang dilaksanakan pun hanya sebatas memperkenalkan lagulagu anak dan menggambar.

Hasil analisis tim pengabdi terhadap wawancara tersebut adalah lemahnya pengetahuan guru mengenai pembelajaran SBDP sehingga guru kurang terampil membawakan pembelajaran SBDP dengan maksimal. SBDP di SD memiliki tujuan yang dapat mengembangkan jasmani dan rohani siswa dalam membentuk kepribadian dan menyiapkan siswa yang memiliki nilai estetis dan memahami perkembangan seni budaya nasional. Tujuan tersebut selaras dengan tujuan kurikulum 2013 bahwa siswa harus mampu mengembangkan keterampilan yang dimiliki (Sinambela, 2017).

Guru sebagai pelaksana proses pembelajaran harus mampu melaksanakan proses pembelajaran SBDP secara terpadu, namun berdasarkan analisis wawancara dengan kepala sekolah menyatakan guru belum sepenuhnya menjalankan pembelajaran sebagaimana mestinya. Hal inilah yang menyebabkan peneliti ingin menemukan permasalah yang lebih detail lagi.

Untuk mendapatkan data yang valid mengenai permasalahan SBDP di sekolah peneliti melakukan penyebaran angket secara online kepada guru-guru SD di alahan panjang. Adapun angket terdiri dari permasalahan tematik terpadu, pembelajaran yang sulit dalam tematik terpadu, jenis SBDP dan permasalahan, faktor yang menghambat dan solusi permasalahan. Adapun hasil angket permasalah tematik terpadu adalah sebagai berikut:

1. $100 \%$ guru menyatakan telah melaksanakan proses pembelajaran terpadu. 100\% guru menyatakan bahwa pembelajaran tematik terpadu sesuai dengan karakteristik siswa sekolah dasar.

2. $62,5 \%$ guru menyatakan masih kesulitan dalam menerapkan pembelajaran terpadu.

3. $87,5 \%$ guru menyatakan bahwa pembelajaran SBDP sulit untuk diterapkan terutama seni musik.

4. $100 \%$ guru menyatakan sekolah telah memiliki alat musik seperti talempong, gendang, drumband, keyboard, pionika.

5. $75 \%$ guru menyatakan tidak bisa menggunakan alat musik yang ada di sekolah.

6. Tentang faktor penghambat, $83 \%$ guru menyatakan kurangnya pemahaman guru terhadap seni yang diajarkan, 15\% guru menyatakan tidak adanya sarana pendukung, 22\% guru menyatakan kurangnya jam yang disediakan.

7. $100 \%$ guru menyatakan setuju untuk diberikan pelatihan mengenai keterampilan bermusik pada pembelajaran kurikulum 2013

Analisis pengabdi terhadap hasil angket ini adalah bahwa guru telah melaksanakan proses pembelajaran tematik terpadu namun belum berjalan dengan optimal. Hal ini dikarenakan guru masih belum mampu membawakan mata pelajaran Bahasa Indonesia, PKN, 
IPS, IPA dan SBDP secara padu, sehingga pembelajaran SBDP yang seharusnya dilaksanakan secara tematik dilaksanakan terpisah. Seni yang menjadi permasalahan utama guru dalam melaksanakan pembelajaran terpadu adalah seni musik. Hasil angket juga membuktikan bahwa faktor kurangnya pengetahuan guru dalam melaksanakan seni musik dalam pembelajaran tematik terpadu adalah kurangnya pemahaman guru dalam pelaksanaan seni musik disekolah dasar. Oleh sebab itu guru sepakat untuk dapat dilatih dalam berseni musik pada pembelajaran kurikulum 2013.

Dari wawancara pengabdi dengan kepala sekolah serta hasil angket yang pengabdi sebarkan secara online nampak permasalahan yang munculnya adalah lemahnya kemampuan dan keterampilan guru dalam seni musik yang mengakibatkan pembelajaran tematik terpadu tidak berjalan dengan optimal.

Pembelajaran seni musik merupakan sebuah wadah komunikasi dalam menyampaikan eksistensi siswa (Ghozali, 2012). Dengan adanya seni musik siswa mampu menyampaikan dan mengutarakan sebuah pesan yang mungkin secara langsung tidak dapat mereka sampaikan. Selain itu seni musik juga merupakan wadah untuk meningkatkan kreativitas siswa, karena dengan bermusik siswa akan dituntut untuk memahami dan mengembangkan harmoni, irama, gaya dan ekpresi (Wicaksono, 2009). Pengabdian ini juga merupakan pengembangan dari hasil penelitian pengabdi pada tahun 2012 yang telah di publikasikan padajurnal denganjudul The Usage of Contextual Teaching and Learning (CTL) Approach to Improve the Process and Learning Outcome of Singing to the Student Class III Elementary School YPKK of Padang State University (Desyandri, 2012). Hasil menunjukan bahwa menggunakan pendekatan CTL dapat meningkatkan kualitas kemampuan bernyanyi siswa sekolah dasar. Selain itu pengabdian ini merupakan hasil dari penelitian
Disertasi pengabdi yang telah pengabdi publikasikan pada seminar nasional dengan judul makalah Peran Warga Sekolah dalam Pembudayaan Nilai-nilai Edukatif Lagu-lagu Minang Melalui Gerakan Literasi di SD (Desyandri, 2017). Penelitian ini menunjukan bahwa dengan lagu minang kabau (literasi budaya) dapat meningkatkan karakter siswa sekolah dasar.

Literasi budaya merupakan pengetahuan tentang kelompok budaya bahkan budaya itu sendiri yang dibutuhkan dalam proses membaca, menulis, dan lainnya (Aprinta, 2013). Hoffman menyatakan bahwa lietrasi budaya merupakan sebuah jaringan informasi yang memahami dan menghubungkan terhadap bahan yang dibaca serta memberi makna terhadap bacaan tersebut (Desyandri, 2018). Literasi budaya sangat penting untuk dikembangkan dikarenakan literasi budaya mampu membangun hubungan sosial (Helaludin, 2018). Artinya litetasi budaya dapat meningkatan sikap toleransi antar individu sehingga ini perlu dikembangkan untuk siswa sekolah dasar. Hal ini berhubungan dengan peran seni musik sebagai media komunikasi. Berdasarkan kenyataan tersebut maka perlu pengabdian yang diberikan kepada guru sekolah dasar yang bertujuan untuk meningkatkan pengetahuan dan keterampilan guru SD dalam pembelajaran seni musik sebagai sarana literasi budaya peserta didik.

\section{METODOLOGI}

Pengabdian ini dilaksanakan untuk guru sekolah dasar digugus Anai Kecamatan Padan Panjang barat Kota Padang Panjang sebanyak 20 orang yang merupankan utusan guru yang berada di gugus tersebut. Lokasi Kegiatan di pusatkan di SDN 18 Silaian Bawah Kota Padang Panjang. Metode pelaksanaan yang dilakukan bertujuan untuk mengatasi permasalahn yang dialami oleh mitra. Dalam PKM ini metode yang digunakan adalah seminar dan pelatihan terbimbing. 
Kegiatan seminar bertujuan untuk menambah pengetahuan guru mengenai SBDP dalam pembelajaran Tematik Terpadu Sebagai sarana literasi budaya. Proses dimulai dengan memberikan pengetahuan kepada guru mengenai hakikat pembelajaran terpadu. Setelah itu guru dibekali dengan materai SBDP dalam pembelajaran tematik. Kemudian dilanjutkan dengan pemberian materi mengenai seni musik sebagai sarana kiterasi budaya. Pada materi ini guru juga dibekali dan dibimbing untuk membelajarkan SBDP (Seni Musik) dalam pembelajaran tematik terpadu. Untuk mengakhiri guru diberikan Quiz yang dijawab secara bersamaan pada ahir kegiatan.

Pelatihan terbimbing bertujuan untuk meningkatkan keterampilan guru mengenai seni musik dalam pembelajaran termatik terpadu. Langkah awal pelatihan dimulai dengan pengenalan alat musik tradisional beserta fungsinya. Setelah guru paham, guru dilatih untuk menggunakan alat musik tradisonal. Hal ini bertujuan untuk meningkatkan keterampilan seni musik guru. Setelah guru mampu memainkan alat musik, guru dilatih untuk mengembangkan seni musik yang sesuai dengan pembelajaran terpadu. Setelah guru mengembangkan seni musik, guru dilati untuk membuat panduan seni musik yang telah di kembangkan. Hal ini bertujuan sebagai penambah referensi seni musik untuk siswa sekolah dasar. Kegiatan diakhiri dengan kegiatan evaluasi.

Evaluasi terdiri dari dua tahapan yaitu evaluasi awal dan evaluasi akhir. Pengabdian dikatakan berrhasil jika terjadinya peningkatan pengetahuan dan keterampilan guru dalam pembelajaran seni musik sebagai literasi budaya.

\section{HASIL DAN PEMBAHASAN}

Kajian pada hasil dan pembahasan dibagi menjadi dua yaitu seminar dan pelatihan. Kegiatan seminar pada pengabdian ini disampaikan oleh bapak Drs. Mansurdin, M.Pd. Adapun Materi yang disampaikan oleh beliau terdiri dari hakikat pembelajaran terpadu, landasan pembelajaran terpadu, prinsip pembelajaran terpadu, dan model pembelajaran terpadu untuk sekolah dasar. Materi disampaikan selama dua jam oleh Bapak Mansurdin. Materi yang disampaikan melalui slide dan penjelasan yang mendetail oleh pemateri. Agar peserta tidak bosan, pemateri menggunakan variasai dalam penyampaian materi.

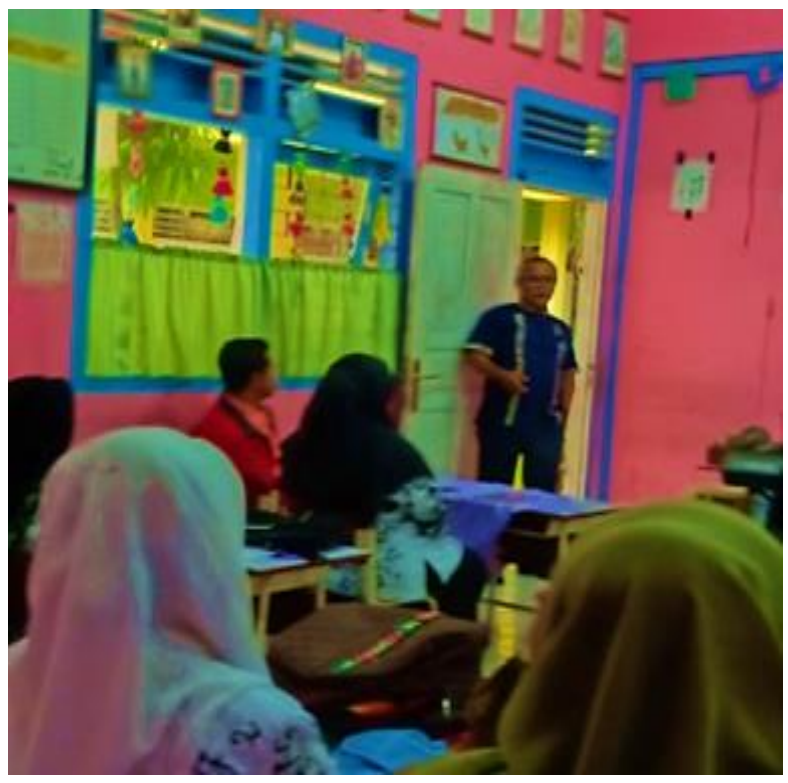

Gambar 1. Drs. Mansurdin, M.Pd. memberikan Materi

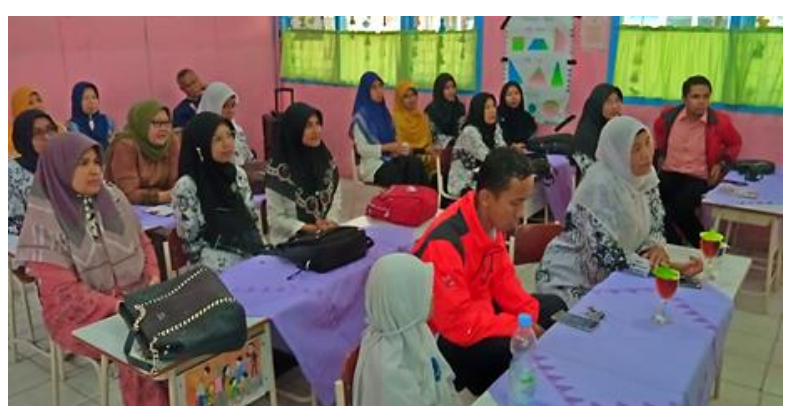

Gambar 2. Peserta mendengar arahan dari Drs. Mansurdin, M.Pd.

Pada akhir kegiatan penyampaian materi oleh Drs. Mansurdin, M.Pd. diadakan sesi tanya jawab. Pada kesempatan ini salah satu guru bertanya mengenai pembelajaran terpadu sebagai berikut: 
"Pak, dalam kurikulum 2013 kan ada buku guru dan buku siswa yang diberikan sebagai pedoman pelaksanaan pembelajaran. Apakah kita boleh menambahkan atau memperdalam materi yang terdapat dalam buku tersebut karena materi yang ada pada buku tersebut masih dangkal, terimakasih pak."

Pertanyaan tersebut dijawab oleh Drs. Mansurdin, M.Pd.. Beliau menyatakan bahwa materi pada kurikulum 2013 boleh dikembangkan dengan syarat tidak mempengaruhi esensi tujuan pembelajaran. Pengembangan materi ini juga harus dilihat dari sudut waktu, karakteristik siswa dan kondisi lingkungan. Setelah bapak mansurdin menyampaiakn materi, belia memberikan evaluasi kepada guru yang bertujuan untuk mengetahui pemahaman guru terhadap materi yang telah disampaikan.

Pada pukul 12.30 guru diistirahatkan dan diminta untuk kumpul kembali pada pukul 13.30 untuk materi selanjutnya. Pada pukul 13.45 WIB, para peserta memasuki ruang workshop. Materi selanjutnya disampaikan oleh Dr. Desyandri, M.Pd. Adapun Materi yang disampaikan mengenai SBDP (Seni Musik) dalam pembelajaran terpadu kurikulum 2013. Dr. Desyandri, M.Pd. menyampaikan materi selama selama dua jam. Peserta antusias dan bersemangat dalam mendengar pemateri menyampaikan materi yang tentunya berguna untuk guru.

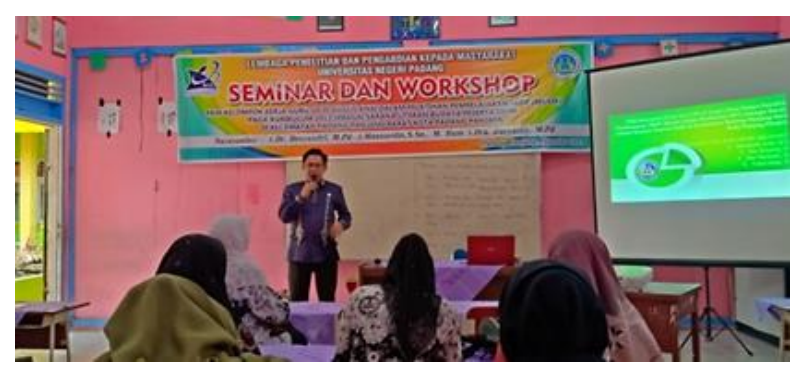

Gambar 3. Peserta mendengar arahan dari Dr. Desyandri, M.Pd.

Pada akhir penyemapaian materi Dr. Desyandri, M.Pd menyampaikan bahwa kurkikulum 2013 memiliki tujuan untuk menghasilkan anak bangsa yang berkarakter melalui kreativitas, inovatifitas dan produktivitas. Kreativitas yang dimiliki oleh guru dan siswa mampu menjawab tantangan masa depan yang menuntut inovasi baru. Oleh sebab itu kurikulum 2013 harus dilaksanakan dengan maksimal agar dapat mecapai tujuan pendidikan nasional. Namun dalam proses pelaksaanaanya pun perlu faktor-faktor yang salain berpengaruhi. Faktor tersebut adalah berkaitan dengan kepala sekolah, guru, siswa, sarana dan prasarana yang saling mendukung satu sama lainya. Terutama pada pembelajaran seni musik yang sangan membuthkan kreativitas guru .

Guru harus mampu secara kreatif memilih bahkan menciptakan media dan metode pembelajaran untuk seni musik. Selain itu guru harus mampu memperdalam wawasan dan mengembangkan suasana belajar sehingga tercipatnya proses belajar aktif dalam seni musik. Selain itu dibutuhkan kompetensi guru seperti kemampuan komunikasi, kurikulun, strategi belajar dan penilaian. Proses belajar yang baik bukan lah tdilihat dari kurikulum yang dimiliki saja namun melainkan ada halhal lain yang menunjang seperti hubungan antar manusia. Mengajar dengan menyelearaskan kurikulum adalah hal yan baik namun mengekploirasi kurikulum 2013 sehingga enjadi pembelajaran yang bermakna adalah labih baik lagi.

Pada pukul 15.45, Dr. Desyandri, M.Pd. mengakhiri pemateri dengan membuka sesi pertanyaan. Adapun pada sesi ada satu pertanyaan sebagai berikut:

"Pak, dalam materi seni musik di kurikulum 2013 jarang yang menonjolkan seni musik minang kabau, apakah kita boleh merubahnya?"

Lalu Dr. Desyandri, M.Pd. menjawab sebagai berikut:

"Boleh asalkan tetap mengajarkan esensi budaya yang teretar padabuku guru" 
Pada pukul 15.55 WIB acara worskhop hari pertama selesai. Dr. Desyandri, M.Pd. menyampaiakan bahwa kegiatan selanjutnya dilaksanakan pada tanggal 10 Agustsus 2019. Sebelum menutup acara, bapak desyandri melakukan evaluasi dengan memberikan soal-soal yang berkaitan dengan materi yang telah disampaikan.

Berdasarkan evaluasi mengenai materi yang telah disampaikan saat seminar dapat terlihat adanya peningkatan pemahaman guru. Berdasarkan data terlihat bahwa terjadinya peningkatan pemahaman guru terhadap materi yang disampaiakan. Adapun hasilnya dapat dilihat pada gambar dibawah ini:

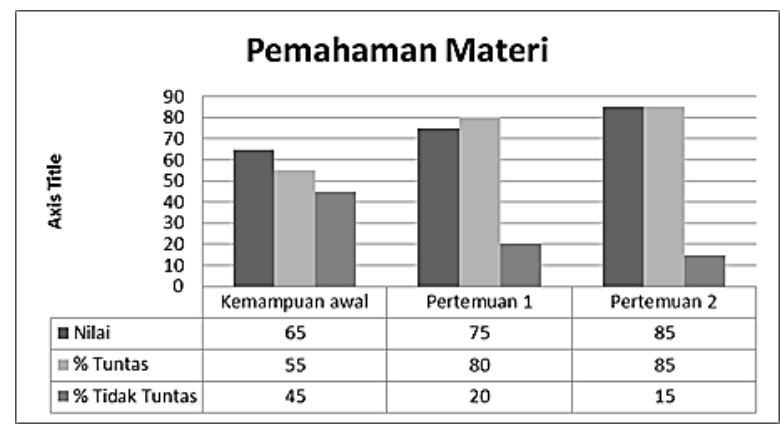

Gambar 4. Diagram Kemampuan Pengetahuan Guru Melihat Seni Dalam Pembelajaran Terpadu

Selanjutnya adalah kegiatan pelatihan yang bertujuan untuk melatih kemampuan guru dalam seni musik. Pada pelatihan ini Drs. Mansurdin, M.Pd. langsung mempraktekan kegiatan cara memainkan alat musik talempong, gendang dan bansi. Pemateri sangat piawai dalam memainkan ketiga alat musik tersebut. Irama yang dihasilkan dari alat musik minang kabau sangat indah sehingga menambah ketertarikan peserta pelatihan untuk bisa memaikan alat musik tersebut dan melestarikannya serta menerapkan ilmu pengetahuannya tentang alat musik di Sekolah Dasar.

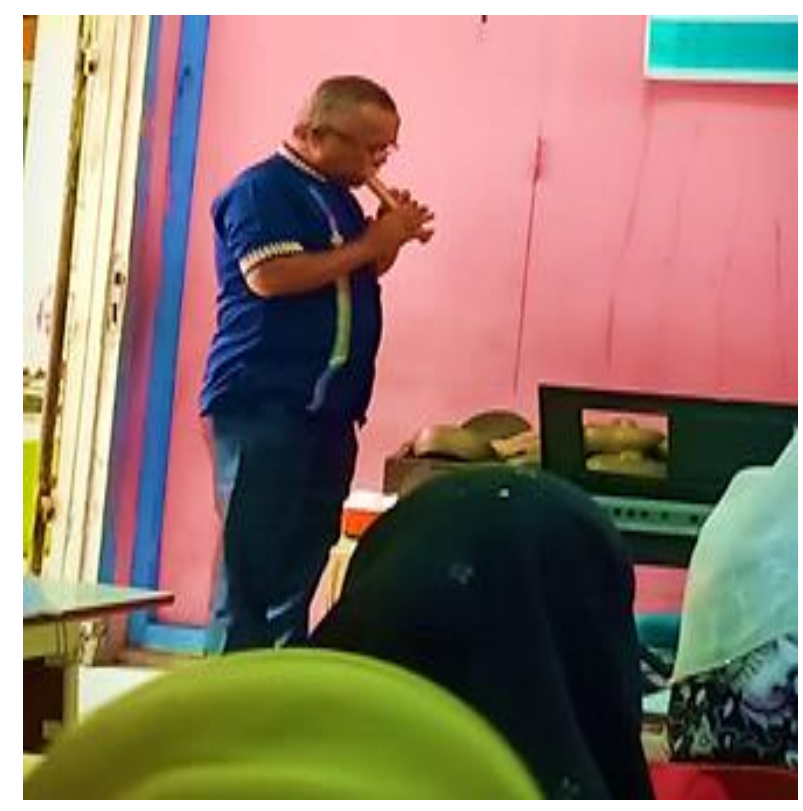

Gambar 5. Drs. Mansurdin, M.Pd. mempraktekan Bansi

Kegiatan ini dilaksanakan sampai pukul 12.30. Kemudian dilanjutkan kembali pada pukul 13.30 WIB. Kegiatan pada jam ini difokuskan untuk mengajarkan keterampilan guru SD dalam memainkan alat musik tradisional tersebut dengan teknik dasar. Perwakilan dari peserta mencoba untuk mendemonstrasikan cara memainkan alat musik sesuai arahan pemateri dan teknik dasar. Pada Kesempatan ini banyak peserta yang mengangkat tangan menjadi perwakilan memainkan alat musik yang dibawa oleh pemateri, namun dua orang peserta yang terpilih mendemonstrasikan cara memainkan alat musik.

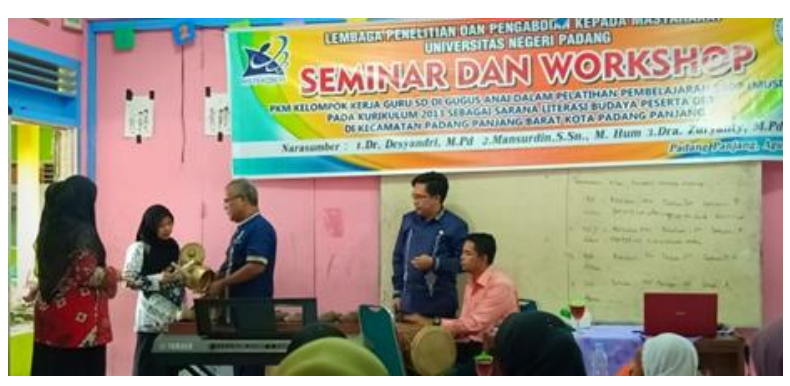

Gambar 6. Praktek Teknik Dasar Seni Musik Minangkabau 


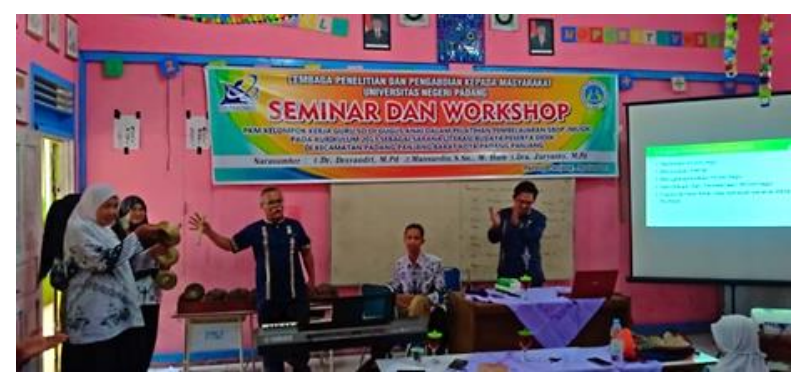

Gambar 7. Praktek Guru bermain Musik

Kegiatan berakhir pada pukul 16.00 WIB. Selama kegiatan dilakukan penilaian proses terhadap kemampuan guru memainkan alat musik. Berdasarkan data tersebut terlihat adanya peningkatan kemampuan guru dalam memainkan alat musik Adapun hasilnya dapat dilihat pada gambar dibawah ini:

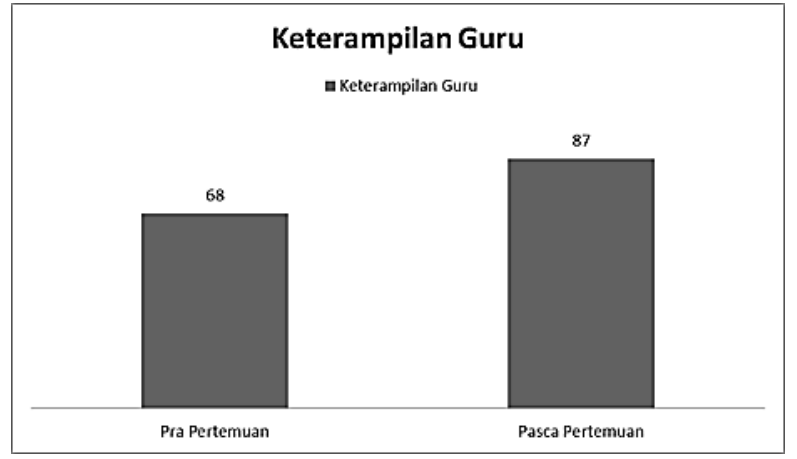

Gambar 8. Keterampilan Guru dalam Memainkan Alat Musik

Secara keseluruhan dapat disimpulkan bahwa terjadinya peningkatan pengetahuan dan keterampilan guru dalam pembelajaran seni musik sebagai saran literasi budaya siswa. Hal ini membuktikan bahwa pengabdian yang dilakukan berhasil. Dalam pengabdian tersebut terlihat guru sangat antusias dan semangat dalam mengikuti kegiatan seminar. Hal ini membuktkan bahwa guru memiliki motivasi untuk mengikuti proses seminar. Motivasi merupakan dorongan yang berasal dari dalam diri seseorang untuk melakukan sesuatu (Nayantaka, 2017; Mahardhika, 2013). Motivasi memiliki pengaruh yang besar terhadap kemampuan individu dalam meningkatkan kualitas diri (Anggraeni, 2011). Termasuk seorang guru. Kualitas guru sangat berdampak terhadap proses pembelajaran. Guru yang memiliki kemampuan pedagogik yang baik akan mampu memciptakan proses pembelajaran yang baik (Hasma, 2017).

Guru harus memahami pembelajaran kurikulum 2013 dengan baik (Suyatmini, 2017). Hal ini dikarenakan kurikulum 2013 merupakan kurikulum nasional yang diterapkan untuk semua level pendidikan di Indonesia. Guru harus mampu membelajarkan kurikulum 2013 dengan baik. Termasuk didalamnya pembelajaran seni musik. Pembelajaran seni musik memiliki tujuan yang selarasa dengan kurikulum 2013 yaitu mencipatkan siswa yang mampu bersikap serat mimiliki rasa (Yuni, 2017). Oleh sebab itu guru harus mampu membelajarakan seni musik dalam proses pembelajaran kurikulum 2013 dengan baik. hal ini bertujuan sebagai proses literasi budaya yang sudah mulai hilang ditengah masyarakat.

\section{KESIMPULAN}

Berdasarkan pegabdian yang dilakukan maka dapat disimpulkan bahwa terjadinya peningkatan pengetahuan dan keterampilan guru dalam pembelajaran seni musik sebagai saranan literasi budaya siswa sekolah dasar.

\section{UCAPAN TERIMA KASIH}

Ucapan terimakasih kepada Universitas Negeri Padang yang telah memberikan bantuan dana terhadap pengabdian ini.

\section{REFERENSI}

Anggraeni, N. 2011. Pengaruh Kemampuan dan Motivasi Terhadap Kinerja Pegawai Pada Sekolah Tinggi Seni Indonesia (STSI) Bandung. Jurnal Penelitian Pendidikan. 12(2):5474. 
Aprinta, G. 2013. Fungsi Media Online Sebagai Media Literasi Budaya Bagi Generasi Muda. Jurnal The Messenger. 5(1):16-30. http://dx.doi.org/10.26623/themessenger.v5 i1.218

Desyandri. 2018. Nilai-Nilai Kearifan Lokal Untuk Menumbuhkembangkan Literasi Budaya Di Sekolah Dasar. Sekolah Dasar Kajian Teori dan Praktik. 27(1):1-9. http://dx.doi.org/10.17977/um009v27i12018 p001

Desyandri. 2017. Peran Warga Sekolah dalam Pembudayaan Nilai-nilai Edukatif Lagu-lagu Minang Melalui Gerakan Literasi di Sekolah Dasar. In: Prosiding Seminar Nasional "Pembelajaran Literasi Lintas Disiplin Ilmu KeSD-an", 4-6 September 2017, Bukittinggi.

Desyandri. 2012. The Usage of Contextual Teaching and Learning (CTL) Approach to improve the process and learning outcome of Singing to the Student Class III Elementary School YPKK of Padang State University. Pedagogi: Jurnal Ilmu Pendidikan. 12(1):36-52.

Ghozali, I. 2012. Pembelajaran Musik Berbasis Siswa Dengan Pendekatan Local Genius. Jurnal Visi Ilmu Pendidikan. 7(1):651-663. http://dx.doi.org/10.26418/jvip.v7i1.334

Hasma, H. 2017. Keterampilan Dasar Guru untuk Menciptakan Suasana Belajar yang Menyenangkan. Didaktis: Jurnal Pendidikan dan Ilmu Pengetahuan. 17(1):23-35. http://dx.doi.org/10.30651/didaktis.v17i1.15 55

Helaludin. 2018. Desain Literasi Budaya dalam Pembelajaran Bahasa Indonesia di Perguruan Tinggi. Estetik. 1(2):101-116. http://dx.doi.org/10.29240/estetik.v1i2.582

Mahardhika, R. 2013. Pengaruh Motivasi Kerja Terhadap Kinerja Karyawan (Survei Karyawan Pada PT. Axa Financial Indonesia Sales Office Malang). Jurnal Administrasi Bisnis. 4(2):1-10.

Nayantaka, J. 2017. Motivasi Berprestasi Mahasiswa yang berasal dari Pulau Mandangin. Character: Jurnal Penelitian Psikologi. 4(1):1-12.

Scharkow, M. 2013. Thematic content analysis using supervised machine learning: An empirical evaluation using German online news. Quality

$$
\begin{array}{lrr}
\mathcal{E} & \text { Quantity. } & \text { 47(2):761-773. } \\
\text { https://doi.org/10.1007/s11135-011-9545-7 }
\end{array}
$$

Siew, N.M., Amir, N., Chong, C.L. 2015. The perceptions of pre-service and in-service teachers regarding a project-based STEM approach to teaching science. SpringerPlus. 4(1):11-22. https://doi.org/10.1186/2193-1801-4-8

Sinambela, P.N.J.M. 2017. Kurikulum 2013 dan Implementasinya dalam Pembelajaran. Generasi Kampus. 6(2):1-10.

Susanto, A. 2013. Teori Belajar dan Pembelajaran di Sekolah Dasar. Jakarta: Kencana Prenada Media Group.

Suyatmini, S. 2017. Implementasi Kurikulum 2013 Pada Pelaksanaan Pembelajaran Akuntansi Di Sekolah Menengah Kejuruan. Jurnal Pendidikan Ilmu Sosial. 27(1):60-68. https://doi.org/10.2317/jpis.v27i1.5120

Wicaksono, H.Y. 2009. Kreativitas dalam pembelajaran musik. Cakrawala Pendidikan. 1(1):1-12. https://doi.org/10.21831/cp.v1i1.42

Yuni, Q.F. 2017. Kreativitas Dalam Pembelajaran Seni Musik Di Sekolah Dasar: Suatu Tinjauan Konseptual. Elementary: Islamic Teacher Journal. 4(1):55-77. http://dx.doi.org/10.21043/elementary.v4i1. 1980 